Biospecies Vol. 11 No. 1, January 2018

\title{
Jenis-jenis udang air tawar dan karakteristik habitat di tujuh sungai Kabupaten Aceh Barat Provinsi Aceh
}

\author{
(Type of freshwater shrimp and habitat characteristics in seven rivers in the district of West Aceh, \\ Province Aceh)
}

Rita OKTAVIA

Jurusan Pendidikan Biologi, STKIP Bina Bangsa Meulaboh.

Jl.Nasional Meulaboh-Tapaktuan, Peunaga Cut Kec. Meureubo Kab. Aceh Barat

Provinsi Aceh 23615

E-mail: ritaoktavia87@gmail.com

\begin{abstract}
This study aims to determine the species of freshwater shrimp and habitat character in District West Aceh. The research conducted in April - July 2014, include at seven observation site, Used purposive sampling methode. At each station, samples were collected for 30-45 minutes with a length of 3-5 m sampling area along the river in a direction against the current. Samples were taken to the Basic Biology Laboratory of STKIP Bina Bangsa Meulaboh, for further identification. The identification of shrimp based on morphological features, taxonomic characteristics and body measurements. Shrimp habitats in each site are described and documented. There are five species of freshwater shrimp found in West Aceh, ie: Macrobrachium rosenbergii, M.empulipke, M. equidens, $M$. australe, and $M$. lanchesteri. There are different species of Freshwater shrimp found in different habitat characters.
\end{abstract}

Keywords: Identification, Aceh, Macrobrachium, habitat characters

\begin{abstract}
Abstrak
Penelitian ini bertujuan untuk mengetahui jenis udang air tawar dan karakter habitat yang terdapat di kabupaten Aceh Barat. Penelitian dilakukan pada bulan April - Juli 2014, meliputi Tuju Station. Pengambilan sampel menggunakan metode purposive sampling. Pada setiap stasiun, sampel dikumpulkan selama 30-45 menit dengan panjang daerah sampling 3-5 m di sepanjang sungai dengan arah melawan arus. Sampel dibawa ke Laboratorium Biologi Dasar STKIP Bina Bangsa Meulaboh, untuk selanjutnya diidentifikasi. Identifikasi udang dilakukan berdasarkan ciri-ciri morfologi, ciri-ciri taksonomi dan ukuran-ukuran . Habitat udang disetiap stasiun di_deskripsikan dan di_dokumentasi. Berdasarkan hasil penelitian di Kabupaten Aceh Barat terdapat lima jenis udang, yaitu : Macrobrachium rosenbergii, M.empulipke, $M$ equidens, $M$ australe, dan $M$ lanchesteri. Terdapat perbedaan jenis udang yang ditemukan di karakter habitat yang berbeda.
\end{abstract}

Kata kunci: Identifikasi, Aceh, Macro brachium, karakter habitat

\section{PENDAHULUAN}

Udang merupakan sumber protein yang sering dikonsumsi dan berharga tinggi, serta memiliki banyak manfaat sebagai bahan makanan seperti peyek udang, kerupuk udang, nugget udang, produk dasar dari terasi. Salah satu udang yang umumnya dikenal masyarakat yaitu udang air tawar jenis Macro brachium rosenbergii Klasifikasi udang air tawar di
Aceh Barat belum ter publikasi. Ini merupakan salah satu alasan Peneliti memilih identifikasi dan karakteristik habitat jenis udang di wilayah Aceh yaitu Aceh Barat-. Dibandingkan daerah perairan kabupaten lain seperti Aceh Selatan dan Aceh Barat Daya, Kabupaten Aceh Barat memiliki kekayaan perairan yang cukup tinggi. Melihat luasnya wilayah Aceh yang hingga sekarang terdiri 
atas 23 kabupaten, diharapkan nantinya penelitian ini- akan terus dilakukan sehingga didapatkan data keanekaragaman jenis udang air tawar di Provinsi Aceh

Hipotesis dalam penelitian ini adalah ditemukan variasi jenis-jenis udang air tawar dari tujuh stasiun yang tersebar di wilayah Kabupaten Aceh Barat. Penelitian ini bertujuan untuk mengetahui jenis udang air tawar_dan karakteristik habitat yang terdapat di kabupaten Aceh Barat Provinsi Aceh.

\section{BAHAN DAN METODE}

Penelitian telah dilakukan pada bulan Maret-Agustus 2014. Pengambilan sampel dilakukan di tujuh stasiun yang tersebar di wilayah Aceh Barat. Identifikasi sampel dilakukan pada bulan- Juni-Juli- 2014 di Laboratorium Biologi Dasar, STKIP Bina Bangsa Meulaboh kabupaten Aceh Barat. Penelitian dilakukan di tujuh stasiun yang telah ditetapkan. Stasiun I (di sungai Meureubo), Stasiun II (di sungai Kaway Enam belas), Stasiun III (di sungai Pantondreuh), Stasiun IV (di sungai PanteCeureumen), Stasiun V (di sungai Woyla Induk), Stasiun VI (di sungai Woyla Timur), Stasiun VII (di sungai Woyla Barat).

Metode yang digunakan dalam pengambilan sampel udang adalah purposive sampling, dengan melibatkan beberapa mahasiswa. Pengambilan sampel menggunakan alat tangkap jaring. Dan menggunakan Hand collecting (Tangkap tangan) Pada setiap stasiun, sampel dikumpulkan selama 30-45 menit dengan panjang daerah sampling 3-5 $\mathrm{m}$ di sepanjang sungai dengan arah melawan arus. Pengambilan sampel pada tiap stasiun dilakukan hanya sekali. Sampel yang tertangkap dimasukkan kedalam botol sampel dan diawetkan dalam alkohol $70 \%$ serta diberi label. Sampel dibawa ke Laboratorium Biologi Dasar STKIP Bina Bangsa Meulaboh kabupaten Aceh Barat untuk kemudian diidentifikasi. Identifikasi udang dilakukan berdasarkan ciri-ciri morfologi, taksonomi dan ukuran-ukuran tubuh mengikuti kunci identifikasi Wowor (2004). Dengan rekomendasi refererensi dari Riyanto dkk.2015, Daryanto dkk (2015), Supriadi,A. 2012. Identifikasi difokuskan mengamati bagian morfologi pembeda terdapat pada bagian rostrum, pereopoda dan ukuran tubuh. Rostrum dari jenis udang yang ditemukan memiliki bentuk dan jumlah gigi yang berbeda, baik pada bagian dorsal, maupun ventral.Habitat udang di setiap stasiun dideskripsisikan dan didokumentasi.

\section{HASIL DAN PEMBAHASAN}

\section{A. Spesies Udang di Sungai Aceh Barat}

Berdasarkan hasil penelitian ditemukan sebanyak Lima spesies udang air tawar di Kabupaten Aceh Barat, meliputi: Macrobrachium rosenbergii, M.empulipke, $M$ equidens, $M$ australe, dan $M$ lanchesteri. Adaun karakter dari setiap species di jelaskan sebagai berikut:

\section{Macrobrachium rosenbergii}

Udang memiliki warna dorsal hitam gelap, punggung bercorakf, rostrum dan gigi rostrum jelas terlihat. Bagian cangkang atau kulit terluar keras. Memiliki sepasang capit yang membesar agak melebar. Gigi rostrum sebanyak 13-14 gigi. Ukuran panjang total tubuh sekitar 8-8, $3 \mathrm{~cm}$ (gambar 1). Memiliki karpus periopoda kedua lebih pendek dari chela, karpus berbentuk langsing. Gigi rostrum tidak dapat diamati dengan jelas, hampir tersebar merata. Panjang carapace berkisar 15- $20 \mathrm{~mm}$. Diduga secara morfologi adalah jenis Macrobrachium rosenbergii, berdasarkan Daryanto, dkk (2015) dan Wowor (2004).

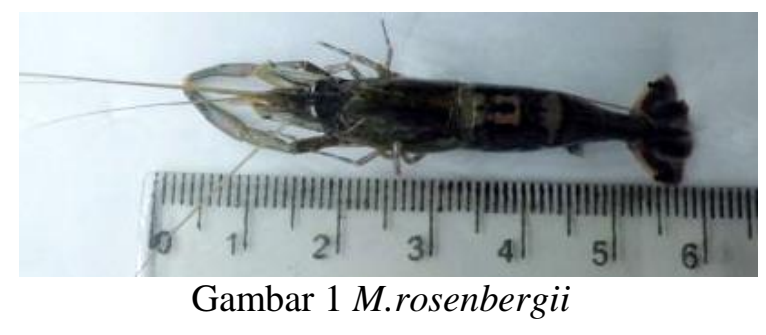




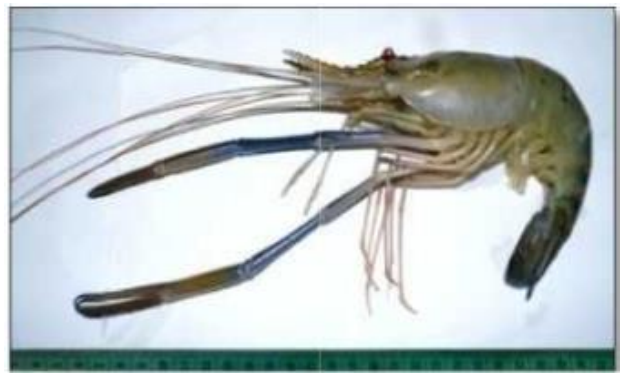

Gambar 2 M.rosenbergii (Daryanto, dkk 2015)

\section{Macrobrachium empulipke}

Udang memiliki warna putih agak coklat, punggung bermotif atau bercorak bintik-bintik hitam, rustrum dan gigi rustrum terlihat jelas, namun agak sulit menghitung gigi rostrum. Bagian cangkang atau kulit terluar kurang keras. Memiliki sepasang capit yang membesar agak melebar. Ukuran total panjang tubuh mencapai 6-6, $5 \mathrm{~cm}$ (gambar 3). Spesies memiliki ciri yang sama dengan Macrobrachium empulipke. Karakter lain karpus periopoda kedua lebih pendek dari chela, karpus berbentuk langsing. Gigi rostrum tidak dapat diamati dengan jelas, hampir tersebar merata. Secara morfologi Menurut supriadi, A (2012) jenis udang ini termasuk dalam Macrobrachium empulipke (Gambar 3).

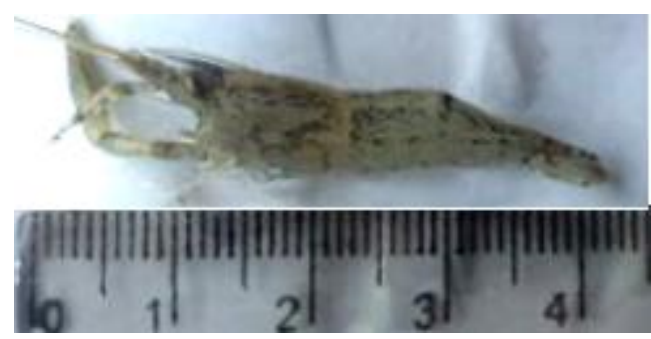

Gambar 3 Macrobrachium empulipke

\section{Macrobrachium equidens}

Udang memiliki warna agak hitam, punggung tidak bercorak, hanya bagian tengah tubuh cenderung memiliki warna yang lebih cerah dibanding bagian ekor dan kepala. memilikii rostrum dengan gigi dorsal yaitu 910 gigi. Tersebar merata dan tidak ada bagian yang tidak bergigi. ciri morfologi bahwa karpus periopoda kedua lebih pendek dari chela. Berbentuk langsing. Panjang carapace mencapai 25-27 mm. Mempunyai sepasang capit yang dominan memanjang kurus atau ramping tidak melebar dan besar. Bagian cangkang atau kulit terluar keras. Ukuran total panjang tubuh $10,5 \mathrm{~cm}$ hingga $11,5 \mathrm{~cm}$. (Warna tubuh terlihat berpola yaitu antara bagian ekor dengan bagian kepala. Dari ciri morfologi tersebut spesies ini adalah Macrobrachium equidens berdasarkan (Riyanto, dkk.2015) (Gambar 4,5,dan 6).

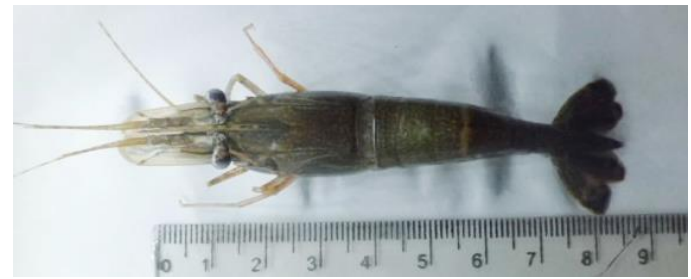

Gambar 4 Macrobrachium equidens 


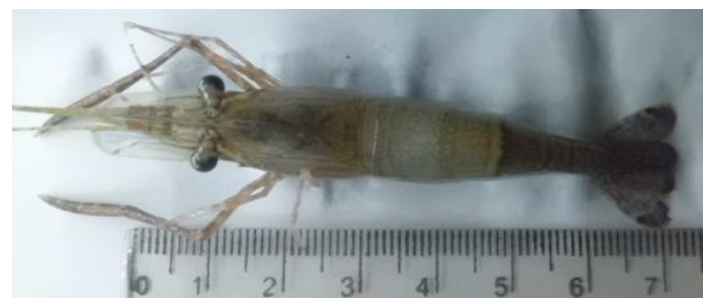

Gambar 5 Macrobrachium equidens

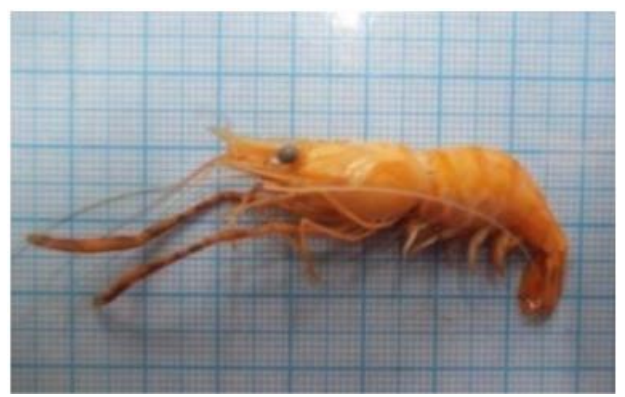

Gambar 6 Macrobrachium equidens (Riyanto,I ,dkk.2015)

\section{Macrobarchium australe}

Udang Jenis ini dicirikan dengan warna tubuh coklat muda hingga coklat tua. Tipe capit jenis ini yaitu capit yang membesar atau melebar. Gigi rostrum terlihat jelas dan dapat diamati yaitu memiliki 12 gigi rostrum.
Ukuran panjang total tubuh spesies udang 10,8 $\mathrm{cm}$ hingga $11 \mathrm{~cm}$. Panjang carapace berkisar 20-25 mm. Bagian kepala kult terluar sangat keras. Hampir seluruh tubuh kulit terluar sangat keras, dan punggung bercorak (gambar 7).

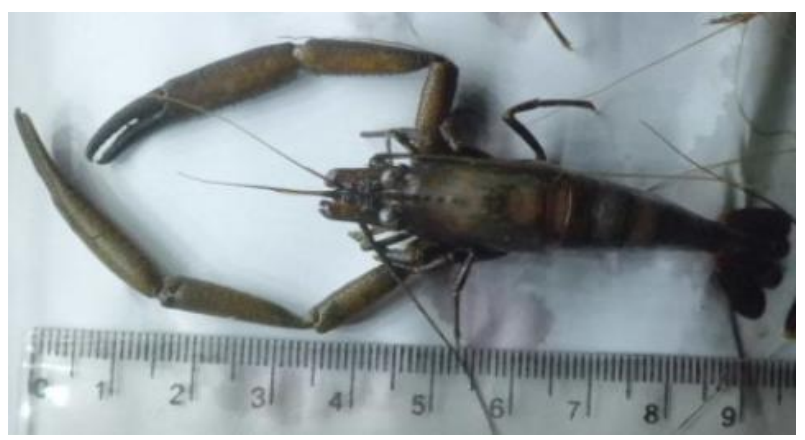

Gambar 7 Macrobarchium australe

Secara umum memiliki ciri morfologi bahwa karpus periopoda kedua lebih pendek dari chela. Berbentuk langsing. Sedangkan gigi rostrum tersebar merata dan tidak ada bagian yang tidak bergigi. Termasuk jenis

\section{Macrobrachium lanchesteri}

Udang ini memiliki ciri yang unik yaitu tubuh berwarna putih bersih tanpa corak. Jika dibandingkan dengan juvenil jenis udang yang memiliki corak sebelumnya seharusnya pada ukuran saat ini sudah memiliki corak. Dengan demikian ini bukanlah juvenil dari udang sebelumnya. Dan warna putih jelas terlihat kecil kemungkinan terindikasi akan menuju warna coklat seperti jenis sebelumnya
Macrobarchium australe berdasarkan identifikasi jumlah gigi dorsal pada rostrum, dan panjang carapace (Rahmi, Annawati, dan Fahri 2016).

yang telah dijelaskan. Ukuran tubuh total udang ini yaitu 6,5 hingga $7 \mathrm{~cm}$ (gambar 8). Rostrum pada spesies ini memiliki gigi tidak tersebar merata dan pada ujung rostrum ada bagian yag tidak bergigi. Panjang carapace 13 $\mathrm{cm}$. Morfologi tubuh panjang langsing. Karpusnya lebih panjang dari chela. Ciri ini merupakan ciri dari jenis Macrobrachium lanchesteri (Wowor 2004) dan (Daryanto, dkk , 2015, Supriadi A. 2012) (Gambar 8, dan 9) 


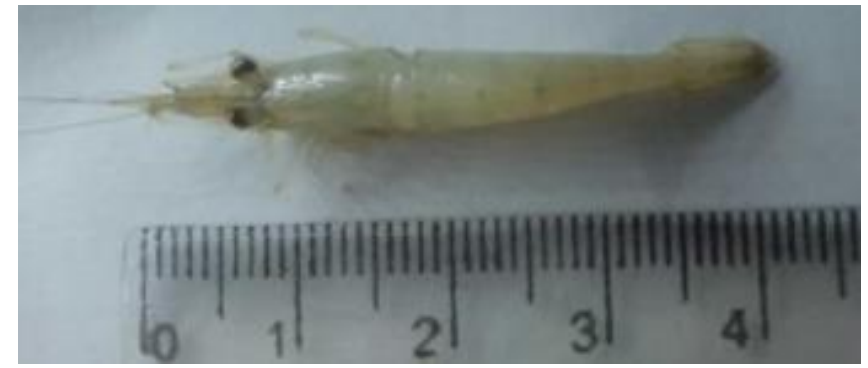

Gambar 8 Macrobrachium lanchesteri

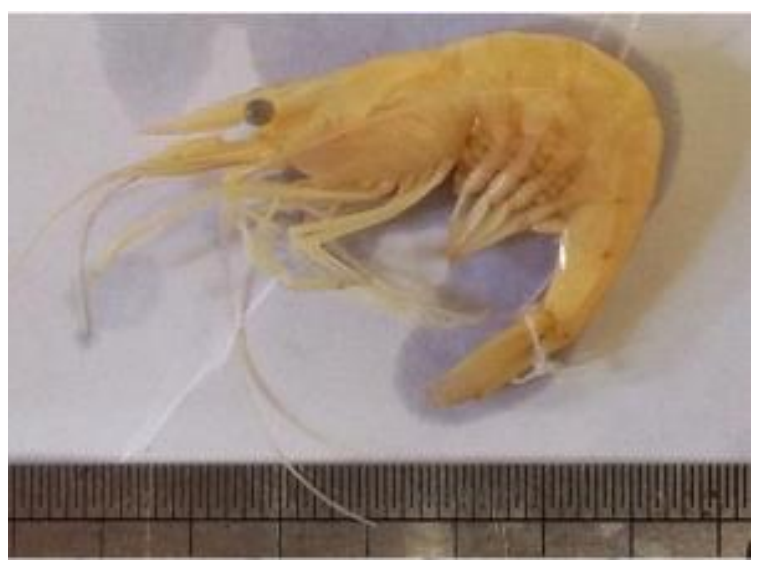

Gambar 9 Macrobrachium lanchesteri (Supriadi,A. 2012)

6

\section{. Macrobrachium cf lanchesteri}

Ciri morfologi udang ini memiliki warna tubuh putih transparan dengan warna oranyge pada ujung ekor dan bagian kepala hingga antena. Bentuk tubuh kurus ramping kecil atau tidak ditemukan ukuran yang lebih besar dan panjang dari ini. Memiliki garis berwarna putih ditengah bagian dorsal punggung. Memiliki rostrum yang gigigiginya begitu halus. Rostrum halus hingga melewati mulut. Semua antena cenderung panjang. Tidak memiliki capit. Ukuran total panjang tubuh udang ini sekitar $5-5,3 \mathrm{~cm}$ (Gambar 10 dan 11). Pada spesies ini Rostrum giginya tidak tersebar merata dan pada ujung rostrum ada bagian yang tidak bergigi. Pada spesies ini morfologi tubuh panjang langsing. Karpusnya lebih panjang dari chela. Ciri ini merupakan ciri dari jenis Macrobrachium lanchesteri (Wowor 2004), dan- (Supriadi,A. 2012).

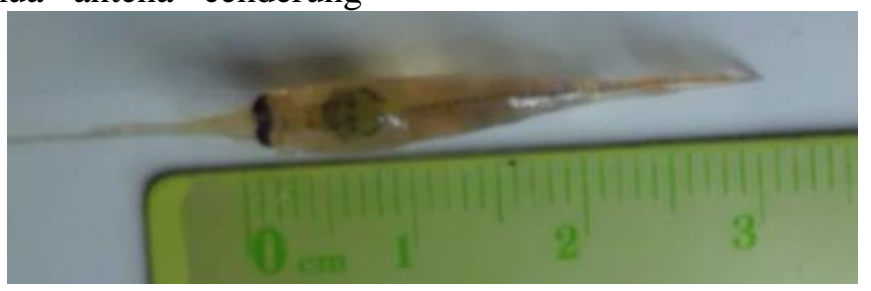

Gambar 10 Spesies udang 7 (Macrobrachium lanchesteri)

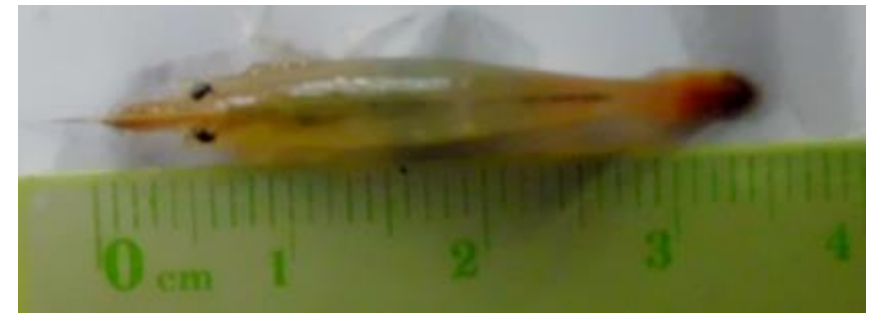

Gambar 11 Spesies udang 9 (Macrobrachium lanchesteri) 


\section{Macrobrachium cf empulipke.}

Spesies udang ini memiliki warna tubuh putih transparan dengan corak berwarna merah. Corak ini ditemukan hingga kesemua bagian tubuh dengan formasi yang dibagian pinggir dorsal. Dibagian tengah punggung ini hanya putih tanpa dipenuhi corak tersebut. Memiliki ukuran tubuh 4,5 cm hingga $5,3 \mathrm{~cm}$. udang ini dilengkapi sepasang capit yang kurus atau ramping kecil dan cendrung transparan (gambar 12).

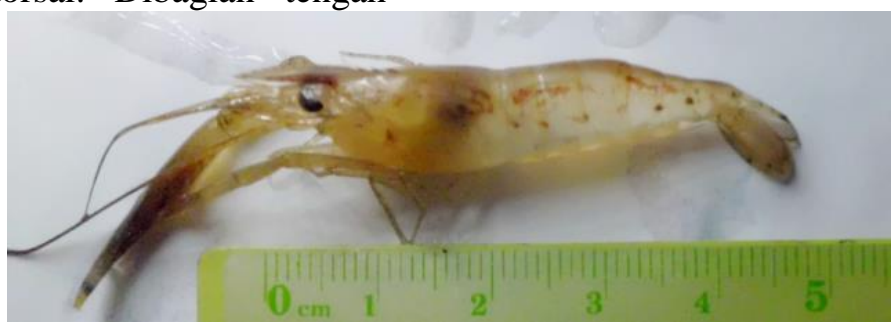

Gambar 12 Macrobrachium empulipke

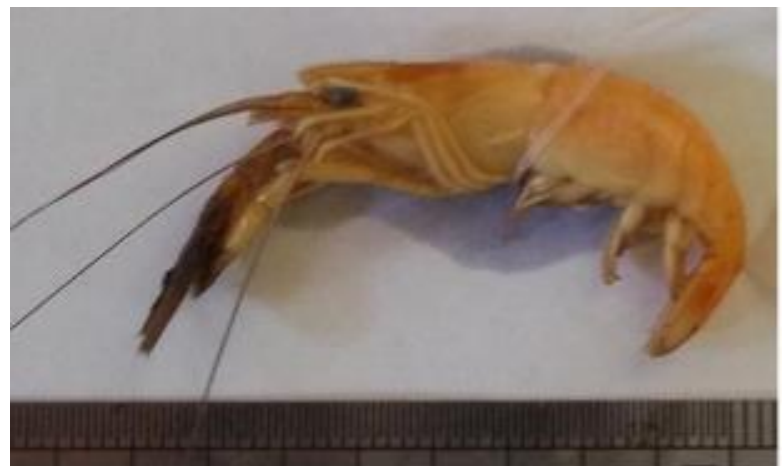

Gambar 13 Macrobrachium empulipke (Supriadi,A 2012)

Udang ini berciri karpus periopoda kedua lebih pendek dari chela. Berbentuk langsing. Sedangkan gigi rostrum tersebar merata dan tidak ada bagian yang tidak bergigi. Menurut supriadi, A (2012) jenis udang ini termasuk dalam Macrobrachium empulipke.

\section{B. Karakteristik Habitat}

\section{Stasiun I}

Pada stasiun I air mengalir namun arus cukup tenang atau tidak berarus. Dipinggir sungai banyak terdapat tumbuhan eceng gondok (Eichornia craasipes). Air keruh atau tidak jernih karena dasar sungai atau substrat adalah tanah berlumpur. Pada lokasi ini sering dilakukan penangkapan udang menggunakan tangguk atau jaring udang oleh warga setempat. Penangkapan dilakukan dari pinggir sungai menyusuri tepi jembatan hingga ke rangka besi (Gambar 14). -Penangkapan sampel udang dilakukan pada pukul 08.55 sampai pukul 09. 45 . 


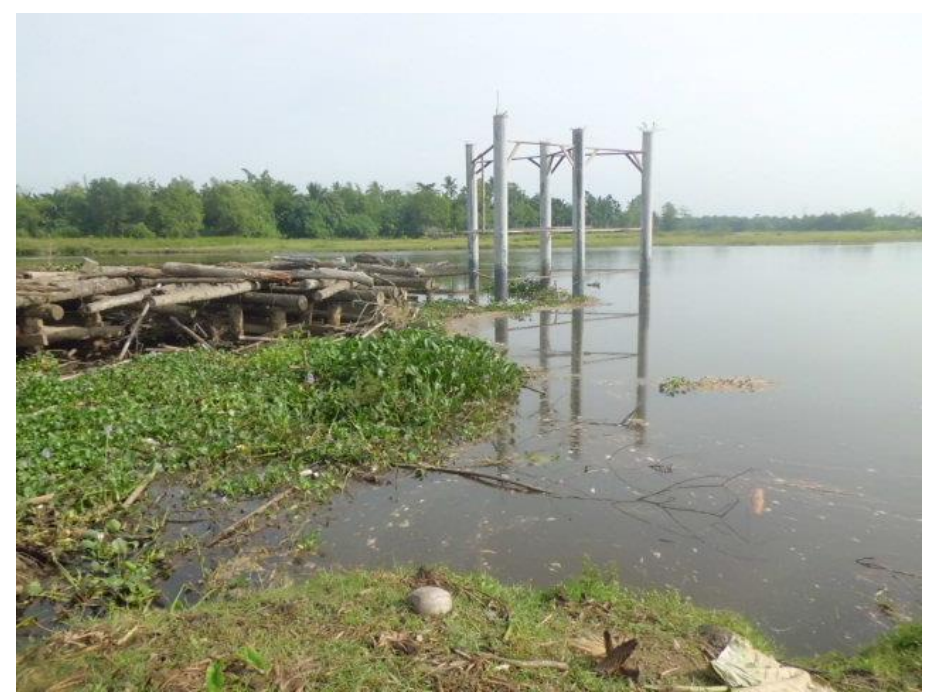

Gambar 14 Habitat stasiun I

\section{Stasiun II}

Pada stasiun II air mengalir, berarus sedang. Dipinggir sungai berbatu, air jernih. Pada lokasi ini penangkapan dilakukan di sepanjang tepi kayu-kayu yang mengering
(Gambar 15). Sering dilakukan pemancingan ikan oleh penduduk setempat. Penangkapan udang dilakukan pada pukul 10.20 sampai pukul 11. 20.

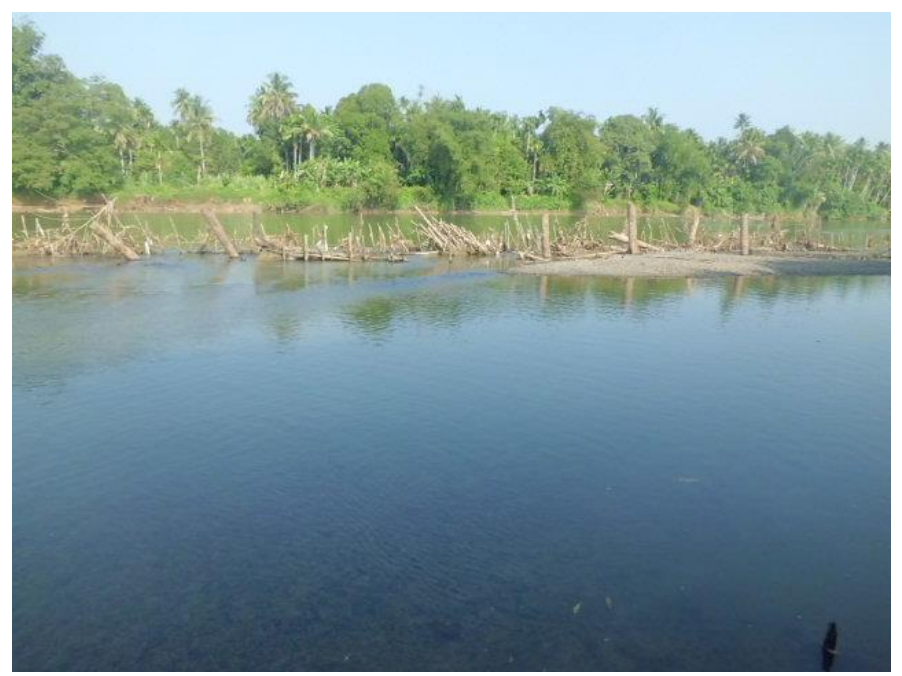

Gambar 15 Habitat Stasiun II

\section{Stasiun III}

Pada stasiun III air mengalir, berarus sedang. Disepanjang pinggir sungai berkerikil. Air jernih karna dasar sungai berbatu. Pada lokasi ini di pinggir sungai tidak terdapat tanaman air atau tumbuhan dipinggir sungai. (Gambar 16). Sering dilakukan penambangan kerikil dan batu oleh warga setempat. Penangkapan udang dilakukan pada pukul 11.40 sampai pukul 12. 40 . 


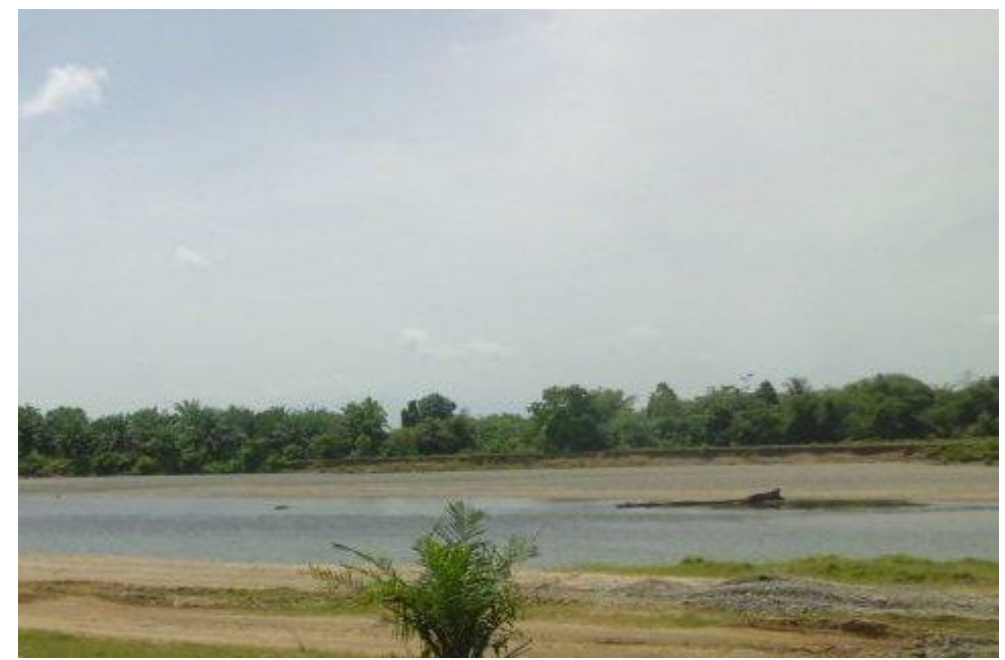

Gambar 16 Habitat Stasiun III

\section{Stasiun IV}

Pada stasiun IV air mengalir, arus cukup kuat. Pinggir sungai banyak terdapat bebatuan. Air jernih karena substrat dasar sungai adalah bebatuan. Udang berada dibawah bebatuan sehingga untuk mengambil sampel harus membalikkan bebatuan tersebut (Gambar 17). Pengambilan sampel nangkapan udang dilakukan pada pukul 08.45 sampai pukul 09. 45 .

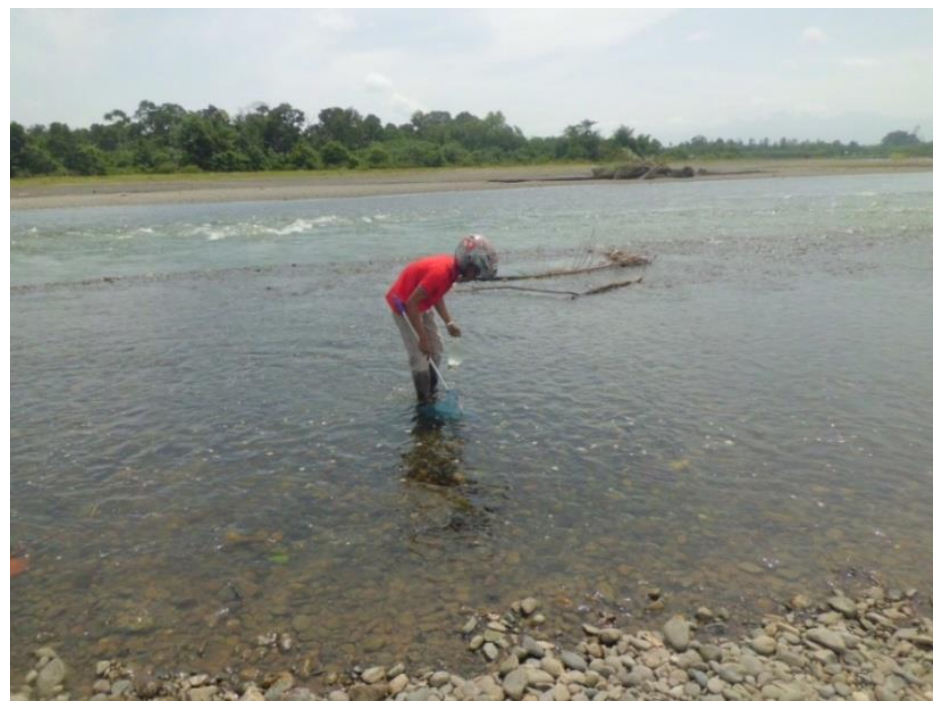

Gambar 17 Habitat Stasiun IV

\section{Stasiun V}

Pada stasiun $\mathrm{V}$ air mengalir, arus perairan tenang. Dipinggiran sungai banyak terdapat tumbuhan air seperti keladi. Penangkapan dilakukan disepanjang tepi sungai tersebut, air tidak jernih atau agak keruh. Substrat sungai adalah tanah (Gambar 18). Pengambilan sampel nangkapan udang dilakukan pada pukul 12.00 sampai pukul 13 . 00 . 


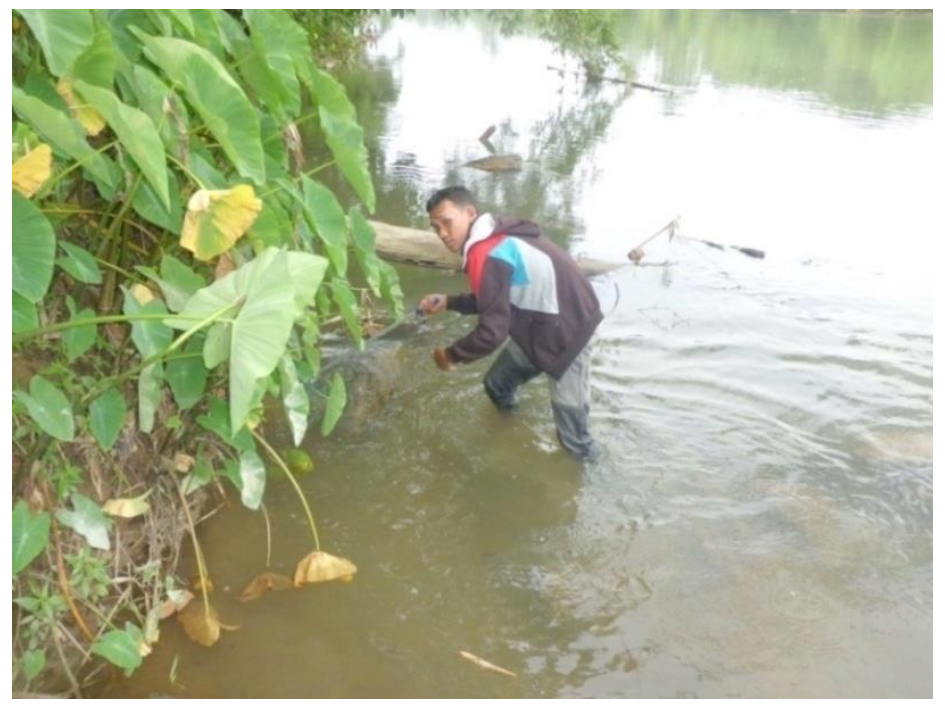

Gambar 18 Habitat Stasiun V

\section{Stasiun VI}

Pada stasiun VI air mengalir, arus cukup tenang. Dipinggiran sungai banyak terdapat tumbuhan. Air tidak jernih karena substrat sungai adalah tanah sehingga kondisi air agak keruh. Cuaca pada hari pengambilan sampel cerah. Pengambilan sampel nangkapan udang dilakukan pada pukul 13. 17 sampai pukul 14. 55 (Gambar 19).

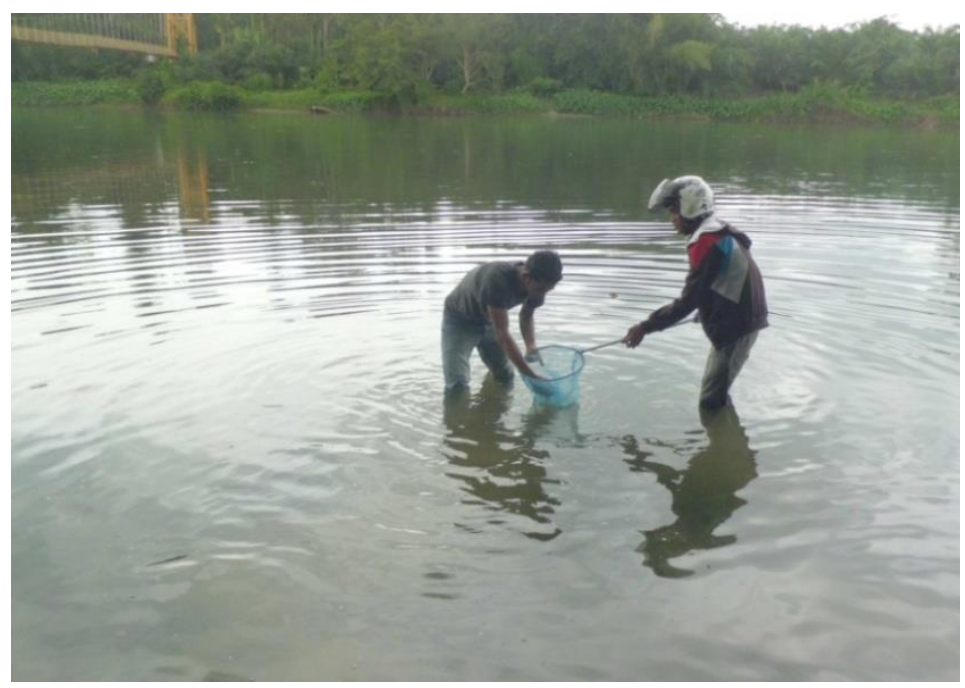

Gambar 19 Habitat Stasiun VI

\section{Stasiun VII}

Pada stasiun VII air mengalir namun arus cukup tenang atau tidak berarus. Dipinggir sungai banyak terdapat tumbuhan dan kayu-kayu yang mengering atau pohon yang tumbuhan tumbang. Air agak keruh atau tidak jernih karna dasar sungai adalah tanah. Penangkapan sampel udang dilakukan pada pukul 08.55 sampai pukul 09. 45 (Gambar 20). 


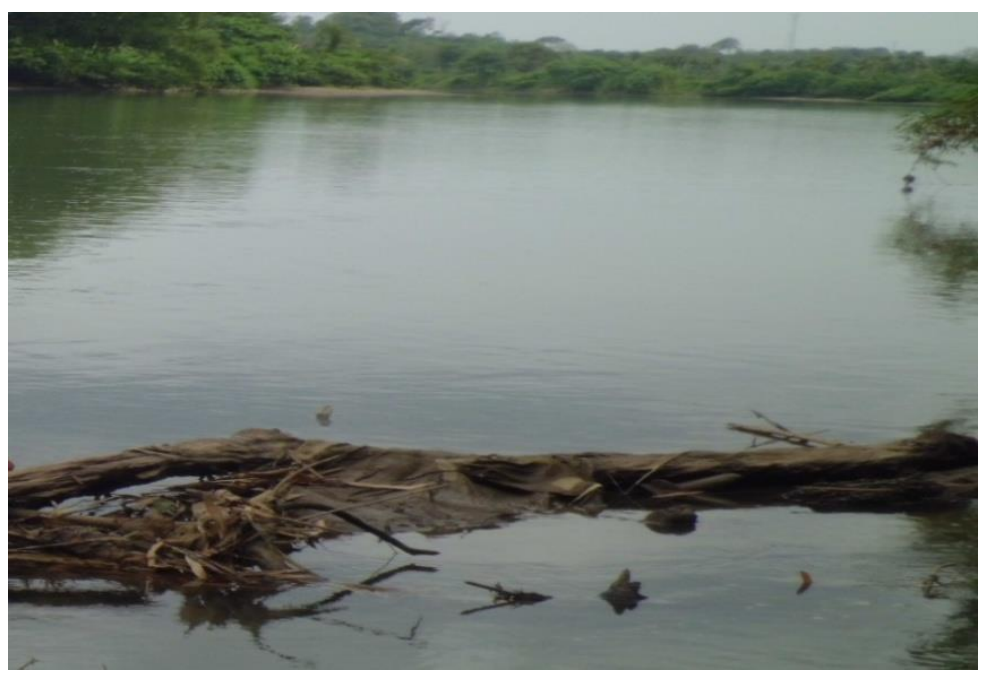

Gambar 20 Habitat Stasiun VII

Pada penelitian ini terdapat lima jenis spesies udang yang ditemukan pada tujuh sungai di Aceh Barat; yaitu Macrobrachium rosenbergii, $M$ empulipke, $M$ equidens, $M$ australe, dan $M$ lanchesteri. Dari

tujuh stasiun pengamatan terdapat dua stasiun yang paling sedikit dijumpai jenis udang yaitu satu jenis. Stasiun ini adalah stasiun tiga dan stasiun tujuh. Kondisi sungai stasiun 3 diketahui bahwa di kedua sungai ini kondisi air jernih. Selain itu juga tidak terdapat tanaman atau tumbuhan dipinggir sungai. Arus air sedang hingga kuat. Substrat dasar sungai berbatu dan berkerikil. Berdasarkan karakter habitat dapat diketahui bahwa udang menyukai sungai yang berarus tenang, terdapat tumbuhan atau kayu-kayuan baik ditepi atau ditengah sungai. Selain itu kejernihan air belum bisa menjadi tolak ukur bayak tidak spesies udang. Waktu penangkapan juga menjadi hal yang perlu dipertimbangkan dalam mengkoleksi data atau sampel.

Aspek perairan yang diukur atau dideskripsikan meliputi kedalaman, kondisi arus, dasar sungai dan suhu. Berikut data kondisi fisika perairan (Tabel 1):

Tabel 1 Kondisi Fisika Perairan

\begin{tabular}{llllllll}
\hline Parameter & Stasiun Pengamatan & & & & & \\
\cline { 2 - 8 } & I & II & III & IV & V & VI & VII \\
\hline Kedalaman/ cm & $85-1120$ & $85-280$ & $85-280$ & $240-420$ & $75-420$ & $75-700$ & $75-420$ \\
\hline Kondisi arus & Tenang & Sedang & Sedang & Kuat & Tenang & Tenang & Tenang \\
\hline Dasar sungai & Tanah & Berbatu & Berbatu & Berbatu & Tanah & Tanah & Tanah \\
\hline Suhu $/{ }^{\circ} \mathrm{C}$ & $30{ }^{\circ} \mathrm{C}$ & $28,5^{\circ} \mathrm{C}$ & $28,8{ }^{\circ} \mathrm{C}$ & $30{ }^{\circ} \mathrm{C}$ & $30{ }^{\circ} \mathrm{C}$ & $29{ }^{\circ} \mathrm{C}$ & $30{ }^{\circ} \mathrm{C}$ \\
\hline
\end{tabular}

Data kondisi fisika dan kimia yang diukur yaitu suhu perairan, kedalaman, dan kondisi arus perairan. Suhu tertinggi yang ditemukan yaitu $30{ }^{\circ} \mathrm{C}$ dan terendah $28,5^{\circ} \mathrm{C}$. Kedalaman sungai terdalam yang ditemukan yaitu $560 \mathrm{~cm}$ dan kedalaman terendah yaitu $85 \mathrm{~cm}$. Kondisi arus pada sungai yang ditemukan bervariasi yaitu arus tenang, sedang dan kuat

\section{KESIMPULAN}

Ditemukan lima jenis spesies udang di Aceh Barat; yaitu : $M$ rosenbergii, $M$ empulipke, $M$ equidens, $M$. australe, dan $M$ lanchesteri. Pada karakter habitat yang berbeda ditemukan jenis udang yang berbeda

\section{UCAPAN TERIMAKASIH}

Terimakasih kepada kementerian riset, teknologi dan pendidikan tinggi republik indonesia yang telah memberikan donasi dana penelitian ini dalam bentuk hibah penelitian dosen pemula tahun 2014. 


\section{DAFTAR PUSTAKA}

Castro P, Huber ME. 2003. Marine Biology. Fourth edition. The MCGraw-Hill Companies.

Daryanto, Hamidah A, dan Kartika WD. 2015. Keanekaragaman Jenis Udang Air Tawar di Danau Teluk Jambi City. Jurnal Biospesies 8(1): 13-19.

Hasashy MM, Sharshar KM, dan Hassan MMS. 2012. Morphological and histologcal studies on the embryonic development of the freshwater prawn, Macrobrachium rosenbergii (Crustacea, Decapoda). The Journal of Basic \& applied Zoology 65: 157-165.

Holthuis LB. 1980. Shrimps and prawns of the world an annotated catalog of species of interest to fisheres. FAO Fish Synop 125: 340-350.

Martin JW, and Davis GE. 2001. An update classification of recent Crustacea. Los Angeles, California: Nat History Mus of Los Angeles Country 39: 1-115.

Mulyadi, Wowor D. 2004. Pengumpulan Lapangan Krustacea. LIPI: Bogor.

Mulyati T, Fahri dan Annawaty.2016. Iventarisasi udang air tawar Gebus Caridina di sungai Poboya Palu, Sulawesi Tengah. Online Jurnal of Natural Science 5(1):83-96.

Rahmi, Annawaty, dan Fahri. 2016. Keanekaragaman jenis udang air tawar di sungai Tinombo Kecamatan Tinombo Kabupaten Perigi Moutong
Provinsi Sulawesi Tengah. Online journal of Natural Science. 5(2): 199208.

Rustiyawatie A, Dharmono, dan Hardiansyah H. 2009. Identtifikasi dan kerapatan udang di bawah tumbuhan nipah kawasan mangrove desa Swarangan Kecamatan Jorong Kabuptaen Tanah Laut. Jurnal Wahana-Bio 1: 51-60.

Riyanto I. dkk. 2015. Keragaman Jenis udang di laguna Baros, Kabupaten Bantul, Yogyakarta. PROSiding SEMinar NASsional MASYarakat BIODIVersitas INDONsia. Volume 1, (3):438-443.

Sugiarto T. 2010. Budidaya Udang. Bandung. Sinergi Pustaka Indonesia.

Supriadi A. 2012. Keanekaragaman Jenis udang air tawar di sungai-sungai yang berasal dari gunung salak. [Skripsi]. Bogor: Fakultas Matematika dan Ilmu Pengetahuan Alam. Institut Pertanian Bogor.

Taufik. 2011. Biodiversitas udang air tawar di danau Kerinci Provinsi Jambi. Tesis. Fakultas Matematika dan Ilmu Pengatahuan Alam. Institut Pertanian Bogor. Bogor.

Wowor D, Cai Y, Ng PKL. 2004. Crustacea: Decapoda, Caridea. Di dalam: Yule $\mathrm{CM}$, Sen YH, editor. Freshwater Invertebrata Of The Malaysian Region. Kuala Lumpur: Akademi Sains Malaysia: 337-357 . Kuala Lumpur. 